\title{
Evaluation of different litter materials on haematogical and serum biochemical indices of intensively managed finisher broiler chickens
}

Obikaonu, H. O., Obiora, S. N. and Obiagwu, P.

Department of Animal Science and Technology,

Federal University of Technology

P.M.B. 1526, Owerri, Imo State, Nigeria

Abstract

Corresponding author: helenogechifuto@gmail.com; 08035447997

Attempts made to improve broiler production had been focused more on feed with little or no consideration on the impact of litter quality which is a major concern in chicken production not only because it affects the flock health and productivity, but also because it may act as potential reservoir and transmission vehicle for pathogens and potential pathogens. Since blood is considered as an important material for the evaluation of health status in animals, there is need therefore, to investigate the impact of different litter materials on the hematological and serum biochemistry of broiler finisher chicken. A 56-day feeding trial was conducted to evaulate the effect of different litter materials on the haematological and serum biochemical indices of intensively managed finisher broilers. Four different litter materials were used for the experiment viz wood, shaving, Groundnut hulls; coconut husks and rice hulls. Wood shavings was used as the control owing to the fact that it is the most commonly used litter in this zone. The coconut husks were manually shred to extract the fibres which was used while the other materials were used as sourced. A toal of 120 broiler birds were used for the experiment, they were divided into four treatments $(T 1=$ Wood shavings, $T 2=$ Groundnut hulls, T3=Coconut husks, and T4=Rice hulls) of 30 birds each and sub divided into 10 birds per replicate. Each replicate was housed in a pen fitted with broding facilities. Feed and water were given ad libilum for eight weeks. At the end of the experiment blood was collected from the birds, three per treatment given a total of 12 birds. They were analyzed for haematological and serum biochemical indices. Haemoglobin values compared favourably $(P>0.05)$ with that of the control. $P C V$ values of $T_{2}$ and $T_{3}$ compared favourably well with that of control but significant differences existed $(P<0.05)$ between the PCV value of $T_{4}$ and the other treatments. The lymphocytes and neutrophils were not affected by the bedding materials showing that the litter conditions did not adversely affect the health and welfare of the birds. Serum protein, serum albumin and serum globulin were not affected by treatements $(P>0.05)$ resulting in better protein efficiency ratio recorded in all the treatments. Serum electolytes calcium and phosphorus levels recorded in this study shows no adverse effect on the integrity of the liver in boosting cataion/anaion exchange. The haematological and serum biochemical indices recorded in this study showed no notable health challenges on the birds.

Keywords: Litter materials, haematology, serum biochemistry, finisher broilers

\section{Introduction}

Quality of chicks, feed and water are all of great concern to broiler producers, but quality of litter in broiler houses is rarely given sufficient emphasis (Casey et al., 2017). They further stated that in the broiler house, litter serves to absorb moisture, dilute faecal material, and provide insulation and cushion between the birds and the floor. Poultry litter is an environmental ecosystem with a range of characteristics (Lu et al., 2003; Fries et al., 2005; Lovanh et al., 2007). Although, litter refers to the mixture of bedding material (wood shavings, rice hulls, coconut hulks, groundnut hulls, etc), faecal droppings and 


\section{Evaluation of different litter materials on haematogical and serum biochemical indices}

moisture, the term is used interchangeably with bedding materials (Bjedov et al., 2013). These litter materials are locally available in Nigeria and are usually handled as waste. To obtain maximum broiler production potential, management of the poultry house is essential and one of the managerial practices is the proper maintenance of poultry litter (Abdul Hafeez et al., 2009). According to Casey et al. (2017), broilers do not perform to their genetic potential in a poor environment. Litter conditions may influence poultry health and welfare (Lister, 2009), which in turn affects profits of growers and integrators. Economic losses associated with poor litter in poultry include foot and leg problems, respiratory infections, poor weight gain and feed conversion (Charles, 2005; Musa et al., 2012). Dry litter helps control ammonia levels, provides a healthy flock environment, and reduces footpad burns and breast blisters. Therefore, there is need to make use of litter materials that are good moisture absorbent, less or no ability to become mouldy and have greater tendency to dry. The litter quality is a major concern in chicken production not only because it affects the flock health and productivity (Bilgili et al., 2006; Bjedov et al., 2013; Garces et al., 2013), but it may act as potential reservoir and transmission vehicle for pathogens and potential pathogens (Gilaneh et al., 2016).

Also, litter type can significantly affect the efficiency of birds' immune system and its growth (Gilaneh et al., 2016). Blood is considered as an important material for the evaluation of health status in animals (Ozkan et al., 2011). Blood testing is commonly used to help diagnose illness in animals (Vetstreet, 2011). It acts as a pathological reflector of the status of exposed animals to toxicant and other conditions (Olafedehen et al., 2010).

Haematology refers to the study of the members and morphology of the cellular elements of the blood-the red cells (erythrocytes), white cells (leucocytes) and the platelets (thrombocytes) and the use of the results in the diagnosis and monitoring of disease (Merck Manual, 2012). Haematological studies are of ecological and physiological interest in helping to understand the relationship of blood characteristics to the environment (Ovuru and Ekweozor, 2004). It is also useful in the diagnosis of many diseases as well as investigation of the extent of damage to the blood (Togun et al., 2007). Measurement of haematological parameters provides valuable information in this regard and routinely used in human's and animal's medicines, but unfortunately due to lack of information, blood profile has not been widely used in avian medicine (Talebi et al., 2005). The comparison of haematological indices expands the diagnostic capabilities, allowing for a comprehensive blood monitoring (Gryzinska et al., 2013). Serum is the yellow watery part of the blood that is left after blood has been removed (Burtis et al., 2006). It is extracted from blood samples by centrifuging the sample to separate cellular components and coagulation factors of blood from the liquid part (Hannu and Hanna, 2014). Serum biochemistry refers to the chemical analysis of blood serum. There are many substances in serum, including proteins, enzymes, lipids, hormones, etc. testing for these various substances provides information about organs and tissues in the body as well as the metabolic state of the animal. If a test result is abnormal, it may indicate the presence of disease (Kristiina and Margo, 2015). Haematological and serum analyses are essential to monitor the health status of poultry in general and broilers in particular, although rarely offer sufficient information outline on etiologic diagnosis (Trinca, 2013). 


\section{Obikaonu, Obiora and Obiagwu}

\section{Materials and methods}

\section{Experimental location and duration}

The research was carried out at the Poultry Unit of the Teaching and Research Farm of Federal University of Technology Owerri Imo State while the laboratory analysis on the blood samples were performed at Links medical laboratories in Owerri, Imo state. Owerri is the capital of Imo state located in the south-eastern part of Nigeria. It lies between latitude 4041 and 6031 and longitude 60151 with an average rainfall of $2500 \mathrm{~mm}$, temperature between $26.5^{\circ} \mathrm{C}$ $27.5^{\circ} \mathrm{C}$ and during the wet season, it has a mean annual relative humidity of $70-80 \%$ (Adeyemi, 2011). The experiment lasted for the duration of eight weeks.

\section{Collection of experimental material}

The different litter materials that were used were locally sourced. While the groundnut hulls were gotten from Bauchi state (also available in Owerri but its quantity is affected by season). The coconut husks were first manually shred to extract the fibres which were used as litter while the other materials were used as gotten. The wood shavings served as the experiment control material.

\section{Experimental diet}

Four experimental diets were formulated such that all the treatments contain the same ingredient levels; its only source of variation is the litter materials. The diets were balanced for crude protein and caloric content as per the requirement of this class of birds in the tropies (Sansbury, 1980).

\section{Experimental birds and design}

A total of 120 , one day-old broiler chicks were used for the experiment. The birds were divided into four treatments $(\mathrm{T} 1=$ wood shavings, $\mathrm{T} 2=$ groundnut hull, $\mathrm{T} 3=$ coconut husks and $\mathrm{T} 4=$ rice hulls) and they

Table 1: Ingredient composition of the broiler finisher diet

\begin{tabular}{|c|c|c|c|c|}
\hline Ingredients & $\begin{array}{l}\text { T1 } \\
\text { (Wood shavings) } \\
\text { (control) }\end{array}$ & $\begin{array}{l}\text { T2 } \\
\text { (Groundnut hulls ) }\end{array}$ & $\begin{array}{l}\text { T3 } \\
\text { (Coconut husks) }\end{array}$ & $\begin{array}{l}\text { T4 } \\
\text { (Rice hulls) }\end{array}$ \\
\hline Maize & 60.00 & 60.00 & 60.00 & 60.00 \\
\hline Soybean meal & 20.00 & 20.00 & 20.00 & 20.00 \\
\hline Wheat offal & 8.00 & 8.00 & 8.00 & 8.00 \\
\hline Palm kernel cake & 3.50 & 3.50 & 3.50 & 3.50 \\
\hline Fish meal & 2.50 & 2.50 & 2.50 & 2.50 \\
\hline Blood meal & 2.00 & 2.00 & 2.00 & 2.00 \\
\hline Bone meal & 3.00 & 3.00 & 3.00 & 3.00 \\
\hline Common salt & 0.25 & 0.25 & 0.25 & 0.25 \\
\hline Vitamin/premix & 0.25 & 0.25 & 0.25 & 0.25 \\
\hline Lysine & 0.25 & 0.25 & 0.25 & 0.25 \\
\hline Methionine & 0.25 & 0.25 & 0.25 & 0.25 \\
\hline TOTAL & 100.00 & 100.00 & 100.00 & 100.00 \\
\hline \multicolumn{5}{|c|}{ Chemical Composition (\% of DM) } \\
\hline \multicolumn{2}{|l|}{ Moisture content } & \multicolumn{3}{|l|}{10.09} \\
\hline \multicolumn{2}{|c|}{ Mineral matter/ash content } & \multicolumn{3}{|l|}{6.85} \\
\hline \multicolumn{2}{|c|}{ Crude fat/ ether extract } & \multicolumn{3}{|l|}{15.90} \\
\hline \multicolumn{2}{|l|}{ Crude protein } & \multicolumn{3}{|l|}{20.00} \\
\hline \multicolumn{2}{|l|}{ Crude fibre } & \multicolumn{3}{|l|}{4.00} \\
\hline \multicolumn{2}{|c|}{ Methabolizable energy $(\mathrm{kcal} / \mathrm{g})$} & \multicolumn{3}{|l|}{2.38} \\
\hline
\end{tabular}




\section{Evaluation of different litter materials on haematogical and serum biochemical indices}

were all given a common environment except for the types of litter. Each treatment was subdivided into three replicates of 10 birds each in a completely randomized design. The birds were all fed ad-libitum two feeding phase (starter ration for the first four weeks and finisher ration for the last four weeks) as shown in Table 1. The birds were also given fresh water ad-libitum. The litters were also periodically turned when the top looks saturated with droppings to discourage caking. Water was strictly prevented from dropping on the litters while taking care of the birds and this ensured a quality litter material that is dry.

\section{Blood collection and analysis}

At the end of the experiment, one bird was randomly selected from each replicate to give 3 birds per treatment with total of 12birds selected. The blood was collected from the jugular vein and blood sample of about $2.5 \mathrm{ml}$ in a $5 \mathrm{ml}$ sterilized syringe was collected per bird for haematological analysis and another $4.5 \mathrm{ml}$ of blood per bird for serum biochemical analysis. The samples for haematology was transferred into a universal bottle containing ethylene diamine tetra acetic acid (EDTA) and mixed thoroughly to prevent the blood from clotting while the blood samples for serum biochemical analysis was transferred into universal bottle without EDTA. Haemoglobin Concentration ( $\mathrm{Hb}$ ) was determined using Sahl method and the value recorded in $\mathrm{g} / 100 \mathrm{mls}$ (WHO, 1980) $\mathrm{RBC}$ and $\mathrm{WBC}$ using the improved Neubauer haemocytometer as described by Dacie and Lewis (1991). PCV was determined by the microhaematocrit method, while mean Corpuscular volume (MCV), mean Corpuscular haemoglobin $\mathrm{MCH}$ and mean Corpuscular haemoglobin MCHL were calculated using the appropriate formulae. The second set of bottles without EDTA was centifuged in a macro centrifuge to obtain Serum for biochemical analysis. Total protein was determined, using the burette method as described by Doumas (1975); urea by dimethylmonoxide method as described by Varley et al. (1980). Serum potassium (K) and Sodium $\left(\mathrm{Na}^{+}\right)$were determined by the Calorimetric method, while serum cholesterol was by a modification of libermann. Burchard test.

\section{Data collection and analysis}

Data obtained on haematology and serum biochemistry were subjected to statistical analysis using completely randomized design (CRD) and treatments were differentiated by one-way analysis of variance (ANOVA) with statistical package (IBM, SPSS version 20). Means were separated by Duncan's multiple range tests (Duncan, 1955).

\section{Results and discussion}

The results on performance of broiler finisher managed intensively on different litter materials is shown on Table 2, there was no significant difference $(\mathrm{P}>0.05)$ in the birds' performance parameter represented above between the treatments. Though the performance of the birds in relation to their total feed consumed, total body weight gain and feed conversion ratio is not part of the aim of this study, they were evaluated to establish the claim by Sigroha et al. (2017), that there were no significant difference $(\mathrm{P}<0.05)$ in the broilers mean cumulative weight gain, mean cumulative feed consumption and mean cumulative feed FCR at the finisher level.

\section{Haematological indices}

The Haematological indices of finisher broilers raised on different litter materials are presented in Table 3 . The $\mathrm{Hb}$ values compared favourably $(\mathrm{P}>0.05)$ with that of control. PCV values of $\mathrm{T}_{4}$ compared favourably well with the control. Significant differences existed $(\mathrm{P}<0.05)$ between the PCV value of $\mathrm{T}_{4}$ and the other treatments, with $\mathrm{T}_{4}$ recording the highest value of $(32.43 \%)$. According to Edozien 
and Switzer, (1977) $\mathrm{Hb}$ and PCV are very sensitive to levels of protein intake as the value increases with increase in dietary protein concentration suggesting that the birds received normal diets throughout the experiment. There were also no significant ( $\mathrm{P}>0.05)$ differences among the treatments in $\mathrm{RBC}$ showing no form of RBC damage in the birds Jain (1986) TWBC of all the treatment groups compared favourably with that of the control. The lymphocytes and Neutrophils were not affected by the bedding materials. Showing that the litter conditions did not adversely affect the health and welfare of the birds (Lister, 2009).

Table 2: Performance of broiler finisher birds raised on different litter materials

\begin{tabular}{llllll}
\hline Parameter & $\begin{array}{l}\mathbf{T}_{\mathbf{1}} \text { (Wood } \\
\text { shavings) }\end{array}$ & $\begin{array}{l}\mathbf{T}_{\mathbf{2}} \text { (Groundnut } \\
\text { hulls) }\end{array}$ & $\begin{array}{l}\mathbf{T}_{\mathbf{3}} \text { (Coconut } \\
\text { husks) }\end{array}$ & $\mathbf{T}_{\mathbf{4}}$ (Rice hulls) & SEM \\
& 4470.40 & 4464.40 & 4456.70 & 4627.40 & +107.30 \\
\hline Total Feed Intake $(\mathrm{g})$ & 158.99 & 159.44 & 159.49 & 165.26 & 3.86 \\
Daily Feed Intake (g & 1345.00 & 1435.00 & 1390.00 & 1430.00 & +58.95 \\
Initial weight (g) & 2693.30 & 2663.30 & 2613.30 & 2709.30 & +83.24 \\
Final weight (g) & 1348.30 & 1228.30 & 1223.30 & 1279.30 & +70.56 \\
Total weight gained (g) & 3.32 & 3.66 & 3.67 & 3.62 & +0.23 \\
FCR & 1.51 & 1.37 & 1.37 & 1.38 & 0.08 \\
PER & &
\end{tabular}

Means within the same row without superscripts are not significantly different $(\mathrm{P}>0.05)$

Table 3: Haematological value of broiler finisher birds raised on four different litter materials

\begin{tabular}{|c|c|c|c|c|c|}
\hline Parameter & $\begin{array}{l}\mathbf{T}_{1} \quad \text { (Wood } \\
\text { shavings) } \\
\text { (control) }\end{array}$ & $\begin{array}{l}\mathbf{T}_{2} \text { (Groundnut } \\
\text { hulls) }\end{array}$ & $\begin{array}{l}\mathbf{T}_{3} \text { (Coconut } \\
\text { husks) }\end{array}$ & $\begin{array}{ll}\mathbf{T}_{4} & \text { (Rice } \\
\text { hulls) } & \end{array}$ & SEM \\
\hline $\mathrm{PCV}(\%)$ & $30.57^{\mathrm{b}}$ & $29.70^{\mathrm{b}}$ & $29.07^{\mathrm{b}}$ & $32.43^{\mathrm{a}}$ & +0.44 \\
\hline $\mathrm{HB}(\mathrm{g} / \mathrm{dL})$ & 16.17 & 14.80 & 15.63 & 16.63 & +0.44 \\
\hline $\mathrm{RBC}(\mathrm{x} 10-12 / \mathrm{L})$ & 2.57 & 2.66 & 2.49 & 2.71 & +0.04 \\
\hline MCV (fl) & 119.11 & 111.66 & 116.93 & 120.35 & +1.67 \\
\hline $\mathrm{MCH}(\mathrm{pg})$ & 62.99 & 55.74 & 62.88 & 61.52 & +1.69 \\
\hline $\operatorname{MCHC}(\mathrm{g} / \mathrm{dL})$ & 52.90 & 49.89 & 53.79 & 51.27 & +1.37 \\
\hline TWBC (x109/L) & 119.47 & 120.03 & 123.37 & 126.20 & +1.28 \\
\hline LYM (x109/L) & 103.15 & 104.80 & 108.13 & 109.47 & +1.20 \\
\hline NEUT (x109/L) & 15.92 & 14.44 & 14.43 & 16.00 & +0.69 \\
\hline
\end{tabular}

${ }^{\mathrm{ab}}$ Means within the same row with similar superscripts are significantly different at $\mathrm{P}<0.05$

Serum biochemical analysis

Serum biochemical indices

The serum biochemical indices of the birds are shown in Table 4. Serum bicochemical result showed no significant differnces $(\mathrm{P}>0.05)$ in the serum protein between the treatment, supporting the work of Isaac et al. (2013) which states that animals with good blood composition are likely to show good performances this can also be attributed to the high protein efficiency ratios and better feed conversion recorded in all the treatments indicating that the bedding materials did not pose any threat to the birds (Kristina and Margo 2015). Serum albumin and globulin also indicated no significant difference in all the treatments indicating availability of protein (Hoffenberg et al. 1966). Uric acid of the treatments $\mathrm{T}_{1}-\mathrm{T}_{3}$ maintained similar trend apart from $\mathrm{T}_{4}$ with slightly lower value of $9.00 \mathrm{u}$ ldl $(\mathrm{P}<0.05)$ storing indicating a possibility of proper renal function and efficient excretion of uric acid whose high levels in the blood can be detrimental (Ehilich, 2016). Age of birds is a factor influencing serum biochemical indices of birds. Oluyemi et al. (2002) reported that growing chikens (8-10 weeks) had significantly greater aspantate amino transferase and alanine transfarase values than adult ( $50-80$ weeks) birds. The values 


\section{Evaluation of different litter materials on haematogical and serum biochemical indices}

recorded for ALT, AST and ACP in this study might be as a result of age. (Arslan et al. 2011). The serum haematological and serum biochemical indices records in this study showing that the condition of the litters did not adversely affect the health and welfare of the birds (Leister, 2009).

Table 4: Biochemistry result of broiler finisher birds raised on four different litter materials

\begin{tabular}{llllll}
\hline Parameter & $\begin{array}{l}\mathbf{T}_{\mathbf{1}} \text { (Wood } \\
\text { shavings) }\end{array}$ & $\begin{array}{l}\mathbf{T}_{\mathbf{2}} \text { (Groundnut } \\
\text { hulls) }\end{array}$ & $\begin{array}{l}\mathbf{T}_{\mathbf{3}} \text { (Coconut } \\
\text { husks) }\end{array}$ & $\begin{array}{l}\mathbf{T}_{\mathbf{4}} \text { (Rice } \\
\text { hulls) }\end{array}$ & SEM \\
\hline Creatinine (mg/dL) & 0.28 & 0.28 & 0.28 & 0.25 & +0.01 \\
Uric acid (mg/dL) & $10.20^{\mathrm{a}}$ & $10.10^{\mathrm{a}}$ & $10.93^{\mathrm{a}}$ & $9.00^{\mathrm{b}}$ & +0.25 \\
Calcium (mg/dL) & 8.43 & 7.93 & 8.20 & 8.07 & +0.16 \\
Phosphorus (mg/dL) & $0.73^{\mathrm{b}}$ & $2.50^{\mathrm{a}}$ & $0.37^{\mathrm{b}}$ & $1.03^{\mathrm{b}}$ & +0.28 \\
Protein (g/dL) & 3.40 & 3.10 & 3.20 & 3.07 & +0.10 \\
Albumin (g/dL) & 1.93 & 1.80 & 1.73 & 1.77 & +0.05 \\
Globulin (g/dL) & 12.33 & 1.20 & 1.47 & 1.30 & +0.07 \\
ALT (IU/L) & 12.33 & 13.67 & 7.67 & 11.67 & +1.30 \\
AST (IU/L) & 59.67 & 63.00 & 64.00 & 64.00 & +1.04 \\
ALP (IU/L) & $219.33^{\mathrm{ab}}$ & $193.33^{\mathrm{b}}$ & $351.33^{\mathrm{ab}}$ & $327.67^{\mathrm{a}}$ & +27.57 \\
\hline
\end{tabular}

${ }^{\mathrm{ab}}$ Means within the same row with similar superscripts are significantly different at $\mathrm{P}<0.05$

\section{Conclusion}

The study showed that groundnut hulls, coconut husks and rice hulls can be used as alternative bedding materials in poultry production without any damage on the performance and blood parameters of the experimental birds. The author also suggested that further research should be carried out on litter materials while putting into consideration the litter depth.

\section{References}

Abdul Hafeez, Suhail, S. M., Durrani, F. R., Dawood Jan, Ahmad, I., Chand, N. and Altafur, R. 2009. Effect of different types of locally available litter materials on the performance of broiler chicks. Sarhadj. Agric. Vol.25, no 4.

Adeyemi, A. 2011. Complete Guide to Nigeria Tourism, Local culture and Investment opportunities. http://www.cometonigeria.com

Arslam, M., Ozcan, E. M., Matur, E., Cotelioghi, U. and Ergui, E. 2001. The effects of vitamin $\mathrm{E}$ on some blood parameters in broilers. Turk.
J. Vet. Anim. Sci., 25: $711-716$.

Banfi, G. and Salvagno, G. L. 2007. The role of ethylenediamine tetra acetic acid (EDTA) as an invitro anticoagulant for diagnostic purposes. Clinic chem. Lab. Med., vol.45 (5):565-760

Bilgil, S. F., Hess, J. B. and Nagaraj, M. 2006. Influence of age and sex on footpad quality and yield in broilers chickens reared on low and high density diets. J. Appl. Poult. Res. Vol.15 (3):433-441.

Bjedov, S., Zikie, D., Perie, L., Dukic and Milosevic, N. 2013. Effect of different litter treatments on production performance of broiler chickens. Biotechnology in Animal Husbandry; vol. 29(4):625-630

Burtis, C. A., Ashwood, E. R. and Bruns, D. E. 2006. Tietz textbook of clinical chemistry ( $4^{\text {th }}$ ed.). saunder p.2448. ISBN: 978-0-7216-01892

Casey, W. R., Brian, D. F. and Michael, P. L. 2017. Litter quality and broiler performance. University of Georgia Extension bulletin 1267 


\section{Obikaonu, Obiora and Obiagwu}

Charles, E. B. 2005. Litter management for confined Turkeys. Poultry sci. and Technical guide. The north Carolina Agricultural Extension service bulletin; 4:3-7.

Duncan, D. B. 1955. Multiple range and multiple F-tests. Biometrics. Vol.11 (11):1-42

Edoziem, J. C. and Switzer, B. R. 1977. Effects of dietary protein, fat and energy on blood haemoglobin and haematocrit in rat. J. Nutr, 107: 1016-1021.

Fries, R., Akcan, M., Bandick, N. and Kobe, A. 2005. Microflora of two different types of poultry litter. $B r$. Poult. Sci., 46:668-672.

Garces, A., Afonso, S. M. S., Chilundo, A. and Jairoce, C. T. S. 2013. Evaluation of different litter materials for broiler production in a hot and humid environment: litter characteristics and quality. Journal of appl. Poultry research; 22:168-176.

Gilaneh Taherparvar et al. 2016. Effect of litter treatment on growth performance, intestinal development and selected caecum microbiota in broiler chickens. R.Bras. zootec. Vol.45 (5).

Gryzinska, M., Krauze, M., Klebaniuk, R. and Strachecka, A. 2013. Influence of gender and age on haematological indicators of polbar's breed of chickens. Lublin, Poland.

Hannu, T. K. and Hanna, H. 2014. Serum biochemistry and haematology in blue Fox (Vulpes lagopus). Kannus, Finland.

Hoffenberg, R., Black, E. and Black, J. F. 1966. Serum Metabolites. J. Chin. Invest., 45: $143-150$.

Issac, L. J., Abah, G., Akpan, B. and E k a t t e , I . U . 2013 . Haematological properties of different breeds and sexes of rabbits. Proceedings of the $18^{\text {th }}$ annual conference of Animal Science Association of Nigeria; p. 24-27

Jain, N. C. 1986. Schaulm's Veterinary Haematology. $4^{\text {th }}$ Edition. Lea and Febiger, Philadelphia, USA. Pp: 13 $-27$.

Kristiina, R. and Margo, S.T. 2015. Know your pet serum biochemistry. http://www.vcahospitals.com/kno w- your-pet/s e r u m biochemistry.

Lister, S. A. 2009. Effects of litter moisture on performance, health and welfare. In proceedings of the $17^{\text {th }}$ European symposium on poultry Nutrition, Edinburgh, Scotland; p.23-27.

Lovanh, N., Cook, K. L., Rothrock, M. J., Miles, D. M. and Sistani, K. 2007. Spatial shifts in microbial population structure within poultry litter associated with physiochemical properties. Poult. Sci., 86:1840- 1849

Musa, I. W., Sai'du, L. and Adamu, J. 2012. Outbreak of pod dermatitis (bumble foot) in broilers managed on deep litter in zaria. Nigeria vet. Clin. Bull. J. vet. Teaching Hospital (in press)

Oluyemi, F. O., Oyewale, J. O. and Omolewa, O. F. 2002. Plasma chemistry value in young and adult Nigerian duck (Anas plotymuchus). Israel Vet. Med. Assoc., 157(4): 2002.

Ovuru, S. S. and Ekweozor, I. K. 2004. Haematological changes associated with crude oil ingestion in experimental rabbits. African journal of biotechnology; vol.3 (6): 346-348

Sigroha, R., Devender, S. B., Dipin, C. Y., Sajjan, S. S. and Ashok, K. M. 
2017. Effect of different materials on the performance of broiler chicken. Journal of Animal Research; v7 n4, p.665-671. d o i : $10.5958 / 2277$ 940x.2017.001024

Talebi, A., Asri-Rezaei, S., Rozeh-Chai, R., and Sahraei, R. 2005. Comparative studies on haematology values of broiler strains (Ross, Cobb, Arbor-acres and Arian). International journal of poultry science vol.4 (8):573579

Togun, V. A., Oseni, B. S. A., et al. 2007. Effects of chronic lead administration on the haematological parameters of rabbits: a preliminary study. Proceedings of the $41^{\text {st }}$ conferences of the Agricultural society of Nigeria; $p .341$

Trinca, S. 2013. Analysis of the haematological and biochemical parameters of chickens in the c ontext of physiopharmacological investigations of some medicinal product formulas. University of Agric. Sci. and Vetmed, Cluj-Napoca, Romania

Vetstreet 2011. Serum biochemistry $\begin{array}{llllllllll}p & r & o & f & i & l & \text { e } & \text {. }\end{array}$ http://www.vetstreet.com/care/ser um-biochemistry-profile/

WHO. 1980. Manual of Basic Techniques for a Health Laboratory. World Health Organization, Geneva, pp. $360-406$.

Received: $20^{\text {th }}$ November, 2019 Accepted: $2^{\text {nd }}$ March, 2020 